IZA DP No. 8078

An Empirical Survey of the Ramifications of a Green Economy

Almas Heshmati

March 2014 


\title{
An Empirical Survey of the Ramifications of a Green Economy
}

\author{
Almas Heshmati \\ Sogang University \\ and IZA
}

\section{Discussion Paper No. 8078 \\ March 2014}

\author{
IZA \\ P.O. Box 7240 \\ 53072 Bonn \\ Germany \\ Phone: +49-228-3894-0 \\ Fax: +49-228-3894-180 \\ E-mail: iza@iza.org
}

Any opinions expressed here are those of the author(s) and not those of IZA. Research published in this series may include views on policy, but the institute itself takes no institutional policy positions. The IZA research network is committed to the IZA Guiding Principles of Research Integrity.

The Institute for the Study of Labor (IZA) in Bonn is a local and virtual international research center and a place of communication between science, politics and business. IZA is an independent nonprofit organization supported by Deutsche Post Foundation. The center is associated with the University of Bonn and offers a stimulating research environment through its international network, workshops and conferences, data service, project support, research visits and doctoral program. IZA engages in (i) original and internationally competitive research in all fields of labor economics, (ii) development of policy concepts, and (iii) dissemination of research results and concepts to the interested public.

IZA Discussion Papers often represent preliminary work and are circulated to encourage discussion. Citation of such a paper should account for its provisional character. A revised version may be available directly from the author. 


\begin{abstract}
An Empirical Survey of the Ramifications of a Green Economy

The unprecedented deterioration of our global environment has increased the necessity of relying upon Green Economic policies as critical and effective environmental management tools. The current situation has stimulated extensive research and debate among global interest groups. This has fostered an ever-growing volume of literature that provides a picture of the best measures affecting the establishment of the Green Economy - including its development and outcomes. This paper provides a survey of the green economy in selfcontained form and accessible to the non-specialist readers. First, it reviews the recent developments in green economy: its theoretical foundation, political background and developmental strategies towards genuine, sustainable development. Second, the circular economy, networks, organizations, policies, infrastructure and measurable expected effects are discussed. Third, the theoretical and empirical results and findings regarding the green economy and its practice do lead to a number of conclusions regarding measurement of improvements, achievement of outcomes and identification of causal effects. Finally, summaries of current and possible future Green Development tendencies with a focus upon directions, policy, organizations, capacity, areas and interventions are provided and extensions that can serve as optimal directions for future research and policy are suggested.
\end{abstract}

JEL Classification: D62, H23, K32, L72, O13, Q01, Q20, Q42, Q50, Q56

Keywords: green economy, development strategy, sustainable development, circular economy, green taxes, green jobs, green finances, green consumption, green trade

Corresponding author:

Almas Heshmati

Department of Economics

Sogang University, Room K526

35 Baekbeom-ro, (Sinsu-dong \#1)

Mapo-gu, Seoul 121-742

Korea

E-mail: heshmati@sogang.ac.kr 


\section{Introduction}

The rapid deterioration of the environment and worsening climate situation have increased the necessity of relying upon new and unique policies like the Green Economic policies as effective environmental management tools. The changed condition has stimulated considerable research and debate among various interest groups in society including: economists, technologists, environmentalists, civil society, managers, regulators and decision makers. The growing interest for change and increased allocation of resources to research the environment has fostered an increasing volume of literature providing a comprehensive picture of the best-known measures and practices affecting the direction, development and outcomes of the Green Economy movement.

Green, smart and sustainable are 'buzz words' that in recent years have increasingly been used in association with development and the environment arenas. Great emphasis is placed upon economic development which enhances general human development in its many dimensions. The truth is that Green Economy can be viewed from various perspectives. These include among others: nature and political economy, economic sustainability and security, Green political and system theory and renewable resources and conservation. The main focuses in this review are: (1) the Green political theory and (2) Environmental and energy-related policies. This is consistent with development trends from recent years.

Before dealing with the concept of green economy, we need to clarify what 'green' actually means here. According to Stavrakakis (1997), 'green' does not refer to general ideas of conservation and preservation. Instead, it is used to deal with the emergence of a whole new phenomenon. It was created to refer to the environment and its deterioration; this admission has led to the rise of the new environmental policy. This new policy is radical and changes to the old views are very necessary. This whole concept challenges our ways of acting within our world (Connolly and Smith, 1999). Although 'green' still falls within the context of conservationism and environmentalism, it is of much greater significance than the viewpoint of political analysis. This is the development in the field of green politics and the whole green ideology. What differentiates this new phenomenon from the preceding forms are its universal and political claims about nature, the environmental crisis and their relationship to the human world.

Overall, 'green' environmentalism claims a new agenda which is aimed at restoring the lost harmony between human beings, their use of resources and nature. It is suggested that this new order, conceived on the basis of a certain concept of nature, will eventually lead to a final solution related to the relationship of human beings with nature. In other words, the aim of green ideology is to refine and recreate the political, social and economic foundations of western societies. This re-creation will be a political project based on and constructed around a particular concept of Nature - while conservationism can only lead to particular policy interventions.

A look at the current state of the green economy globally is the main purpose of this study. First, we will review the recent developments in green economy-- its theoretical foundation, political economics and developmental strategies towards sustainable 
development. All these topics will be reviewed. Secondly, the circular economy, networks, organizations, policies and infrastructure will be discussed. Thirdly, we will investigate the results and findings regarding the practice of green economy and the measurement of its improvements to the environment. Finally, we will examine future green developmental tendencies with a focus upon directions, policy, organizations, areas and interventions. Thus, this survey makes a significant contribution to the literature by providing a complete and up-to-date picture of the green economy development and practice from the past two decades.

The remainder of this survey will be organized as follows. Section 2 the concept of green economy is presented. Section 3 develops the green political economy and green development strategy. Section 4 consists of a review of environment and sustainable development. Section 5 is a discussion of green national product and green accounting. Various applications of green economy is reviewed in Section 6. Selected green public policies including governmental policy and interventions are discussed in Section 7. Section 8 is focused upon recent development of green activities. Section 9 summarizes the current and possible future green development tendencies and suggests extensions that can serve as a possible optimal direction for future research and policy.

\section{The Concept of Green Economy}

We learned from Stavrakakis (1997) that the concept of 'green' is used to deal with environment and its deterioration that has led to the rise of a new environmental policy. Connolly and Smith (1999) see this new environmental policy as necessary, but it also challenges our ways of acting. It claims a new order aimed at restoring the lost harmony between human beings and nature. This section discusses the concept of green economy and related theoretical and ideological issues.

The literature on environmental or green policies is growing rapidly and is divided into two waves (Barry, 2001). The first wave of green political theory was primarily concerned with ecologism as an ideology and its critique of industrial society, where the above concept of green had been formulated. The second wave and its development is characterized by a shift from abstract to concrete critique and engages governments in debates with contemporary schools of political theory and political economy, where green economy that we deal with has been introduced. Then green political theory has developed rapidly and gained credibility during its engagement with contemporary political theory debates. It has contributed to an innovative understanding of the present and future political worlds, distributive justice, democracy, the relationship between liberalism, capitalism and sustainability, feminism and gender politics, etc.

Based on this concept, green economy was introduced as a model, claiming that sustainable economic growth requires a balance between the environmental impact of economic growth and the assimilative capacity of the environment. It is also considered as an appropriate and convenient strategy as part of the recovery programs, designed to overcome the global economic crisis. In other words, green economy believes that directing the economic recovery along greener guidelines will not only help the recovery 
itself be successful, but it will also help achieve the long term objective of promoting a sustainable, economic development model. As such, it is a model of economic growth compatible with not only preserving, but also improving the environmental quality (Musu, 2010).

Thus, the green political economy provides coherent analyses and offers resistance to the new wave of economic globalization (Paterson, 2000; Sachs, 1993). It brings together issues of threat from the global biotechnology industry, the dominant capitalist development model, the deepening North-South inequality, concentration of poverty and destitution, the ecological restructuring and modernization, the character of scientific expertise and technological imperatives in public policy making. It is a politics of speaking the truth to power, giving the powerless, the future generations and the non-human world a voice.

In the sense of those mentioned above, green economy, as described by microbiologist Lynn Margulis (Margulis and Fester, 1991), could be basically understood as the term which refers to any theory of economics that views human economic activity as embedded within ecosystems (Matthews and Boltz, 2012). Generally speaking, green economy is a whole economic theory to pursue economic growth based on sustainability with the environment, energy, health and general well-being, strengthened with good governance, regulation, technology and education.

There is an established idea that European civil society, through contestation and communication within and across multiple public spheres, is good for the Green Movement, green politics and ecological democracy. The European Commission envisioned cultivation of environmental NGOs that, in return for participation in policymaking, moderate their demands to fit the Commission's environmental policy agenda (Armstrong, 2002). Hunold (2007) in studying the developing green political theory and the European Union emphasizes the case for a non-integrated civil society. Hunold shows that the Commission's proposals for restructuring its relationship to civil society organizations follow a trajectory from passive to active inclusion of civil society groups. Based on the state-society interactive relation model of Dryzek et al. (2003) it is argued that European civil society is promoting ecological democracy.

Barry (2001) under the title of Justice, Nature and Political Economy, reviews four researches. These include: Politics and the Environment: From Theory to Practice by Connelly and Smith (1999), Fairness and Futurity: Essays on Environmental Sustainability and Social Justice by Dobson (1999), Justice, Property and the Environment: Social and Legal Perspectives by Hayward and Neill (1997) and finally Political Theory and Ecological Values by Hayward (1998). These are characterizing the first wave of green political theory of ecologism and critique of contemporary industrial society and the second wave ecological thought shifting from abstract to concrete critique.

The Political Economy of Sustainability is presented by Paterson (2007) in a review of four books. The first essay is On the Paths to a Green World with an emphasis on political economy of the global environment by Clapp and Dauvergne (2005). The second essay is on Trade and the Environment which focus on theory and evidence by Copeland and 
Taylor (2003). The third essay is on The Natural Advantage of Nations elaborating with business opportunities, innovation and governance in the 21st century by Hargroves and Smith (2005). Finally, the fourth essay is on Globalization and the Environment, focusing on greening global political economy by Kutting (2004). All of these books, despite their diversity, are in agreement that the pursuit of sustainability requires understanding the shape of dynamics in the global political economy.

Berry (2007) in an essay entitled 'A Model of Green Political Economy: From Ecological Modernization to Economic Security' mentions that the weakest aspect of the understanding of sustainable development has been the economic dimension. Berry suggests that ecological modernization is the dominant conceptualization of sustainable development within the UK. The judgment is based on key sustainable development policy documents and awareness of the strategic opportunities of the policy discourse. In particular, it is suggested that the discourse of economic security ought to be used in offering policy-relevant paths to outlining a green political economy that would underpin sustainable development.

Finally, development of green economy understood from the viewpoint of system theory is studied by Zhang and Su (2005). The systemic requirement, hierarchy characteristics and gradual evolution from simple to complex are stated systematically, and the influences of element, structure and environment on the systemic function and evolution of green economy are analyzed.

\section{Green Political Economy and Development Strategy}

In this section, we deal with green political economy, in particular when green economy faces politics. This will allow to see how the green economy concept has been politically employed.

Conventional economics has received critiques emphasizing that it only values marketable aspects of humanity and nature while it overlooks non-market aspects such as ecological concerns. In this situation, given the persistence of economic problems and their effect on the quality of life, the green economy concept has been politically employed. Green economy is challenging the way in which society values nature, and urging the extension of our sense of moral community to other species (Sayer, 2000). In fact, Muuller et al. (2007) shows that green parties have been electorally successful in several European countries since 1980s and finds out the explanations. It shows that green economy does not deny economics. Instead, the dominant paradigm in green political economy accepts the market economy, while proposing that markets should be combined with a thick layer of democratic, non-market institutions to ensure environmental sustainability (Greenwood, 2007). Von Weizsacker (1994) argues for a new economic model which is less harmful to the environment.

As the economic model is politically employed, Mellor (2006) argues that an ecofeminist political economy can make a contribution to a green economy. The ecofeminist political economy sees women's work and lives like the natural world and can make a major 
contribution to this green political economy, where women's work and environmental damage are not valued in monetary terms. In the general sense, it concludes that the conventional market economy takes only what it needs from nature and only provides products and services that are profitable - thus causing damage which is well recognized in green economy (Mellor, 2006). Then green political economy pursues incorporating ecological, political concern and argument with economics methods.

We should note that friction can appear in green political economy between theory and practice. Thus, political effects could turn out to be differentiated among countries. We can take an example in the book by Medonca et al. (2010) entitled Powering the Green Economy. Feed-in tariff (FIT) is considered as the best strategy to implement green energy with a proper incentive mechanism as government legislates that generators of renewable electricity receive a secure and attractive unit price for the sale of their electricity to the local grid. But the book points out the policy's variation in outcomes among countries. Of course, this is because not all countries seek the same outcome (Mendonca et al., 2010).

Some researcher suspect that green politics could not be exclusively concerned with environmental issues. Ciocirlan and Yandle (2003) claim that green tax is to raise tax revenue rather than to discourage polluting activities, showing empirical results based on OECD countries. Also, Svendsen et al. (2001) conducts research on CO2 taxation in OECD which points out that the current green taxation system is far from its optimal design. The authors doubt that there may be an institutional lobby of industries against green taxation, and their empirical findings on CO2 taxation within the OECD countries confirm this theoretical prediction. McCulloch (2008) considers green pressure where he examines the implications for British politics of the increase in concern over the environment over the last 20 years. McCulloch concentrates particularly on the industrial system and its relationship to environmental politics. The blueprint for a green economy is discussed by Pearce et al. (1989). In Jackson's (1990) view, it has provided us with a detailed and thought-provoking contribution to the debate over the uneasy marriage of economics with the environment.

\section{Environment and Sustainable Development}

The development strategy of green economy described in the previous section could be encapsulated as sustainability. This sustainability or sustainable development is an essential element in green economy. Then, a variety of theories and policies are made to conduct the strategy. There is research on sustainable development in general view with broad issues. Archibugi and Nijkamp (1989) point out that sustainable economic development requires the application of an integrated economic-ecological method and analysis. Turner (1992) in a review mentions that the views expressed are representative of the thinking that was prevalent in the mid-1980s. In this period, the concept of sustainability struggled to gain academic precision and policy relevance. Specifically, they argue that sustainability cannot be adequately measured via a single indicator.

Jacobs (1993) is another work on environmental economics, sustainability and its possible political or institutional repercussions in the future. It not only considers market forces as a 
cause of environmental degradation, but also as forces to be utilized in order to achieve sustainability. It presents evidence from an ethical and logical, as well as empirical perspective (see also Opschoor, 1995 for a review). Adams (2001) traces the roots of the sustainable development, indicating the variety of different meanings - including market environmentalism and ecological modernization, which seeks technical and regulatory solutions to environmental problems (see also Klooster 2003 for its review).

By pointing out that cities are not passive spatial units, but may play an active role in producing a sustainable development, Camagni et al. (1998) provides a specific framework for a sustainable economy in a city with static and dynamic perspectives. They suggest development of possible intervention policies to achieve a balanced sustainable city development outcome. The propositions presented include among others: urban sustainability of the physical, economic and social environments, the main fields of intervention policies, policies to enhance cross interaction between environments, income indicators and urban environmental trade-off and tradable permit constraints.

\section{Green National Product, Accounting and Productivity Growth}

In previous sections, we learned that the conventional economics has received critiques emphasizing that the traditional key economic measures only value marketable aspects of humanity and nature while they overlook non-market aspects such as ecological concerns. Attempts to adjust conventional national product measure for environmental damages have been made. Here alternative approaches to adjust economic measures for environmental effects are presented.

Following the concept of the green national product, the national product is adjusted for the value of environmental damages (Aaheim and Nybory, 1995). Weizman (1976) provided a theoretical foundation of green GDP. Asheim (1997) is one of its extensions to adjust the environmental damage in the national accounting to measure sustainability. For instance, this adjusted measure is important when measuring the relative sustainability of economies of resource-rich and resource-poor countries.

Aaheim and Nybory illustrated some difficulties surrounding this green GDP measure. They indicated fundamental problems of Weizman based models, their self-contradictory assumptions and ways of valuing the environment. They argued that the information which green GDP includes may be misinterpreted easily and not reliable. Heberling et al. (2012) devise an economic measure of regional sustainability labelled as green net regional product (GNRP), and apply it in practice to the San Luis Basin, U.S. They estimated GNRP, a metric of weak sustainability, and discussed concerns about their approach and interpretation.

By Green Accounting for A Sustainable Economy, Bartelmus (1999) suggests policy use and analysis of environmental accounts to assess the sustainability of economic growth. In a related study, Cairns (2002) discusses green national income and expenditure. He is distinguishing between the two to shed light on some issues in green national accounting, including capital gains. Although their total is the same, Cairns proposes that different 
types of depreciation should be defined in the income and expenditure and accounts for matters of sensitivity analysis of the result. Boyd (2007) specifically seeks to measure environmental benefit in the situation with no market indicators to be used as proxies. The author devises the concept of 'ecosystem services' to track the environmental value and indicates some points and difficulties to deal with this ecosystem service.

Prieels (1990) prepared a report on value and the environment for the UK Department of the Environment. It aimed to review the state of the art in the area of sustainable development, natural resources accounting and project evaluation. A large number of methods are presented. Xin (2006) proposed new idea of checking the Green GDP. The current national economy checking index system does not tally with the sustainable development. The system can reflect the positive effects of economy activities, but with no regard on the negative effects. Xin puts forward some ideas about the new index method of the green GDP measuring.

The pursuance of high profit and high consumption has caused the natural resource depletion and environmental pollution. Research on the development of a green economy in capital cities of Shandong is conducted by Wang et al. (2011). Results show that green economy is finding a way to solve the contradiction between the economic growth and the resources environment. The research points out the way of realizing the sustainable development and how to carry on green economy by establishing low carbon economy of the province.

Musu (2010) raises the question as to whether green economy is a great expectation or a big illusion? It is reported that simple growth accounting shows that the negative scale effect of economic growth on the environment can be compensated by a composition effect. This will imply increasing the weight of less polluting productions. The technical progress favorable to the environment will make it possible to achieve a sustainable growth path. Mohanty and Deshmukh (1998) emphasize managing the shift towards green productivity. Some strategic directions are provided to induce change by emphasizing maximization of outputs, commensurate with the consumption of inputs.

Qualitative growth suggested by Capra and Henderson (2009) is a conceptual framework for finding solutions to our current global economic crisis that are economically sound, ecologically sustainable, and socially just. In a recent study, Jackson and Victor (2011) assess productivity and work in the green economy through some theoretical reflections and empirical tests. They explore the concept of productivity in post-growth economies and define the 'productivity trap' that arises from the systematic pursuit of labor productivity.

They begin with asking whether improvement in labour productivity really leads to quality lives. The author asserts that this productivity improvement causes lower employment. To escape this productivity trap, the sharing of work is considered. They describe two solutions to remedy this trap. A transformation into green economy is suggested by shifting the focus of economic activities towards a green services sector. Fare et al. (2001) in measurement of productivity distinguish between good and bad outputs. Oh and 
Heshmati (2010) compute environmental sensitive productivity index adjusting productivity index for emissions.

\section{Selected Green Applications}

This section contains the presentation of a number of green applications including the green revolution, the circular economy, green business networks, green products and the consumption of sustainable products, and several other applications by green chemistry, green citizens and green movements.

\subsection{Green Revolution and Changes to Farming Technology}

Policy and regulation is a requirement to correct the places where the market fails in the allocation of scant resources. The agricultural policy cycle, with an emphasis on the nexus between state regulation, the liberalist market economy, and welfare support for the farmers is discussed by Almås (1994). Population increase and increased demand and productivity are important challenges pressuring the resources and environment. Therefore the challenge to produce enough food is more urgent than ever. Horlings and Marsden (2011) are exploring the conceptual dimensions of a new ecological modernization of agriculture, the green revolution that could feed the world.

In recent decades following the openness in China, the green economy and sustainable and effective approach used in resource utilization are viable solutions to improve economic development and to control environmental deterioration in the country. Comments on some of the problems in the environmental resources of agriculture are presented in Huang et al. (2002). Similar environmental conditions may be the case in the United States. The relative importance of the green industry in the U.S. agricultural industry is increasing. Turner and Kriesel (1995) describe the relative size of the green industry and how it is linked to supporting industries.

The Green Revolution has a long tradition. With regard to the Green Revolution in India, Chakravarti (1973) discusses how an introduction of hybrid seed and increased yield might have contributed to solutions in regional disparity, vulnerability and famine. However, no significant effects in this regard can be observed in the real world. As thoughts of green economy development strategy, Yang (2001) discusses the way that green economy should follow. The issues of green revolution and poverty, theoretical and empirical examinations of relation between technology and society, the positive and negative benefits on the poor is critically reviewed by Das (2002). Yapa (2010) emphasizes the ecopolitical economy of the green revolution. Here green revolution represents a series of efforts aimed at increasing food production in Third World countries. The increased food production can be achieved by replacing the traditional varieties of grain with modern high-yielding varieties and the use of modern farming technologies.

As evidenced by the Green Revolution, Foster and Rosenzweig (1996) study technical change and human capital returns and investments. Panel and time-series data describing 
the Green Revolution period in India are used to assess the effects of exogenous technical change on the returns to schooling. As a result of feedback and two-way causality effects, the effects of schooling on the profitability of technical change, and the effects of technical change and school availability on household schooling, investments are further investigated in more detail. In recent years, vertical farming as a modern urban farming technology is introduced to save scarce land and water resources, to reduce transportation and increase the supply of food in densely populated areas (see Despommier, 2013).

Design for the environment with reference to a quality-based model for green product is discussed by Chen (2001). Here green product development addresses environmental issues through product design and innovation, as opposed to the traditional end-of-pipecontrol approach. Chen mentions that green product development is receiving significant attention from different market participants including customers, industries, and governments around the world. Chen develops a quality-based model for analyzing the strategic and policy issues required concerning the development of products with conflicting traditional and environmental attributes.

Certain type of crops like rice, due to their rule as base food staple and re-energizing the green revolution, has historically been the single most important commodity in much of Asia. This has been the case for three important reasons: supply a large share of caloric consumption of food, it is an important share of total rural economic activity, and due to its significant food security and economic rule, it has been a political commodity. Therefore, Dawe (1998) considers rice over time to remain the most important commodity in the Asian region.

The issues of technology adoption in the intensive post-green revolution systems is discussed by Collin et al. (2005). The authors examine technology adoption trends and discuss how technical change continues to play an important role in sustaining productivity growth. The adoption trends have been impacted by several factors such as increased investment in education, development infrastructures, public and private investment, and improved technological capability. The focus is mainly on the irrigated cereals-based systems of Asia, where the green revolution has been more progressive. The authors suggest that major changes with significant impact on technology adoption and productivity growth have occurred.

\subsection{Circular Economy}

An emerging body of literature has come upon an alternative green economy. Some specific forms of the green economy are circular economy (CE), hydrogen economy and low carbon economy. This section is devoted to the CE.

$\mathrm{CE}$ is a relatively new alternative development strategy focusing exclusively on materials and energy use. Yuan et al. (2006) summarized the concept of a CE and its originating background. According to them, the concept of a $\mathrm{CE}$ was first introduced by scholars in China (Zhu, 1998). Since the late 1970s, China had experienced rapid economic growth, which led to a growing concern of serious natural resource scarcity, depletion, 
environmental pollution and degradation associated with the rapid development. In this regard, CE was proposed and formally accepted in 2002 by the central government as a new development strategy that aims to alleviate the contradiction between rapid economic growth and the shortage of raw materials and energy (Su and Zhou, 2005). The CE suggests the circular flow of materials and the use of raw materials through 3R principles: reduction, reuse, and recycling of materials.

Activities over the past several years show that $\mathrm{CE}$ is emerging as an economic strategy rather than a purely environmental strategy. The major objective of the government is to promote the sustainable development of economy and society, while achieving sustainable environmental protection. Serious efforts have been made in practice and analysed through research published in recent years. Geng et al. (2009) and Geng and Doberstein (2008) studied Dalia, a CE-applied city in China. They identify a series of barriers, challenges and opportunities associated with achieving leapfrog development and their implications to successfully implement CE. CE has been introduced as a specific resolution that enables the country to leapfrog its way from environmentally-damaging development to a sustainable path.

$\mathrm{Li}$ et al. (2010) presents that as for the measures to resolve energy conservation problems, policies and programs of the Chinese government related to energy conservation were introduced in combination with China's circular economy structure. Case studies of the development for the enforcement of CE and energy conservation in China's process industries have been conducted. The aim is to analyse the main technical bottlenecks and resource-environment problems with a special emphasis upon energy utilization efficiency, energy consumption mode, and waste emission. Wang and Liu (2007) introduced CE as an effective means with which global world trade and economy are tending towards more of a 'green way' to help face rising environmental standards and green barriers and seek a true comparative advantage.

It is common acknowledge that China's economic miracle has been achieved at the expense of its natural capital and environment. Geng et al. (2011) introduce the unique national CE indicator system in China which provides information on the status of CE implementation and achievement of its goals and outcomes. In addition, they present a critical analysis of such an indicator system. Su et al. (2013) mention that the CE strategy has been implemented and developed in a number of pilot areas in China. Scholars have produced rich studies in regard with the $\mathrm{CE}$ from its fundamental concept to its practical implementation. Successful enforcement of a CE is seen as a way for China to tackle its urgent problem of environmental degradation and material source scarcity. The authors provide a literature review on the CE, aiming to provide a panorama of how this strategy has been developed and implemented. The review covers the concept, current practices, and up-to-date assessment of the CE. To have a numeric concept of how it has developed, they look at the performance of the $\mathrm{CE}$ in Dalian and compare the changes with three other pilot cities - Beijing, Shanghai and Tianjin. The underlying problems and challenges are identified. Finally, they offer a conclusion and recommendations for future improvements.

Overall, there is a lack of driving force for the developing CE. The government behavior in developing the CE needs to be adjusted to contribute to the sustainable development of the 
economy. As seen in development and implementation of $\mathrm{CE}$, the role of government is decisive, which is specified in $\mathrm{Li}$ and Li (2011). Green Barriers are one kind of non-tariff barrier which have evolved from sustainable development theory and environmental protection, but these are compatible with true comparative advantage. Wang and Liu (2007) suggest that the best way to overcome green barriers is to implement circular production processes and clean production techniques.

In comparison and analysis between CE and traditional economic theory, Zhang and Chen (2004) find indications that the two theories are existing side by side and play a part together. Su et al. (2013) recommend that China's government should promote economic incentives through policies to stimulate the behavior of both enterprises and residents. The government needs to continue its support for the major technologies necessary for the CE. In order to improve public awareness and participation, informative activities related to the $\mathrm{CE}$ should be carried out periodically. Improvements regarding the enforcement of legislation, as well as the management system within the government, will enhance the $\mathrm{CE}$ implementation performance.

\subsection{Green Business and Networks}

Johnson (1998) classifies three major perspectives on the greening phenomenon in business. The first, and most common, is that green businesses are a reflection of green consumerism, and the second is that green businesses are a product of public policies and regulation forcing companies and consumers to undergo greening. These views are well reflected in Roarty (1997) who shows that, under the circumstance of a growing trends, green consumerism reflect the increasing number of consumers who prefer to buy products that satisfy high standards of environmental protection. Companies are pulled by these market trends and also pushed by environmental legislation and consumer demand which set higher standards of environmental quality, thus leading them to become proactive in their management of environmental problems. However, Johnson argues that by the third perspective; green businesses are a reflection of the new ecological paradigm.

Furthermore, Zsolnai (2002) presents and analyses two ways that are aiming at ecological sustainability, where ecological sustainability refers to the fact that the ecological value of the natural ecosystems should not be decreasing over time. One is represented by green business movement and another is a different model of community economy, such as community-supported agriculture. Theoretical and empirical results show that the green business paradigm is not sufficient for achieving ecological sustainability but the community economy might be able to meet the requirements of ecological sustainability.

Jamison (2001) in a researcher on environmentalism in an entrepreneurial age who reflects on the greening of industry network (GIN). The GIN is discussed as an example of a contemporary environmental organization. The author asks "Can the GIN be seen as a kind of 1990s-style social movement organization?” It is concluded that the GIN provides a window into the changing world of ecological modernization. It has developed into one of the ruling doctrines of environmental policy in the late 1990s, but it has also lost parts of its original ambitions along the way. 


\subsection{Green Products and Consumption of Sustainable Products}

Hartman (1996) with regard to myths and realities of the new green economy provides details of new research based on surveys showing that the majority of U.S. consumers have strong inclinations to buy earth-sustainable food products. The increased tendency to buy such food products have impacted the food processing industry. The gap between potential demand and actual food sales can be eliminated by turning our focus from supply of new products to demand or needs of the consumer. However, doing so requires a clear understanding of the market. As an illustration, energy conservation and CE in China's process industries is examined as a reference. Based on the introduction of the concept of energy consumption status in China's key energy-consuming process industries, the main technical bottlenecks and resource environment problems are analyzed by Li et al. (2010). The emphasis is especially on energy utilization efficiency, energy consumption mode, and waste emission.

Consumers' willingness to pay for green initiatives in addition to green foods include other areas such as: green markets, private provision of public goods and the hotel industry. Kotchen (2003) develops a general model of private provision of public goods. The model is used to investigate positive and normative consequences of green markets. Kang et al. (2011) examines the willingness of hotel guests to pay a premium for environmentally friendly and sustainable practices of the U.S. hotel industry. Specifically, the goal of this research is to investigate the relationship between the level of hotel guests' environmental concerns and their willingness to pay a premium for a hotel's green initiatives and practices. They find that hotel guests with higher degrees of environmental concerns declare a higher willingness to pay premiums for hotel green initiatives.

Another complementary aspect of greening economy is design for the environment. Chen (2001) presents a quality-based model for green product development which addresses environmental issues through product design and innovation. The model is receiving significant attention from customers, industries, and governments around the world. Chen develops the model for analyzing the strategic and policy issues concerning the development of products with conflicting traditional and environmental attributes. Two major findings show that green product development and stricter environmental standards might not necessarily benefit the environment. Green payments for nonpoint pollution control related to the Clean Water Action Plan is another green area of public goods discussed by James and Gabler (1997). The action plan proposes greater use of economic incentives to reduce agricultural nonpoint-source pollution.

\subsection{Other Green Applications}

The concept of green is multidimensional and increasingly diversified. Here we briefly mention a few additional areas in addition to those discussed above.

Woodhouse and Breyman (2005) discuss green chemistry. They define green chemistry as an attempt to redesign chemical products and synthesis in the way that significantly 
reduces negative health effects and environmental damages. They assert green chemistry can be considered as a social movement in the form of its expanded definition. This is an elite movement in the sense that it is not a mass movement. The authors illustrate some difficulties political progressives have experienced in interacting with these green chemists so as to continue this developmental trend.

Green economy actually requires citizens to employ more responsibility on a larger concept of economy that also considers environment damages. This concept of citizenship is encapsulated in the phrase, 'Think globally, act locally.' According to Smith (2005), citizenship has scarcely been the subject of systematic attention within green political theory. This is surprising given the significance placed on themes such as individual responsibility, empowerment, participation and communal politics within green academic and activist literature. With regard to green citizenship and the social economy, Smith argues that the ethos and structure of organizations within the social economy, such as cooperatives, mutual and voluntary associations, are well-suited to the development of relevant dispositions, skills and capacities.

Shear (2010) asks whether the green economy is a ground for a new revolutionary imaginary. Shear reports on and considers the composition, goals, and practices of some social actors in the green economy movement in Massachusetts. In another research Lehtinen (2007) studies the green waves and globalization with a Nordic view on environmental justice. Lehtinen argues that the dominating interpretations of Western environmentalism have reached a broad, uniform shape. Furthermore, only recently has this unification of shape met with profound criticism.

Li et al. (2009) studied the green movement's perceptions and behavioral intentions. They discuss among others the development of an instrument to examine subjects' awareness and intentions to behave in accordance with what has become known as the 'green movement'. In a related study, Wall (2001) discusses green anti-capitalism, localization of a global manifesto, globalization, neoliberal challenge, radical responses, debt and the dollar empire.

\section{Selected Green Public Politics}

This section covers a selection of common green public policies. The policies include government policies and interventions, green hydrogen economy, green energy, green taxes and low carbon economy.

\subsection{General Government Policies and Interventions}

Chen (2008) is of the view that an optimal government policy model of promoting green economy requires a combined policy and economic blandishment policy. Elander (2007) investigates the path towards a green welfare economy. He studied the behavior of the Green Party in Sweden since the 1998 parliamentary election. Following this election, the party supported a coalition government provided they were granted influence over 
government policies with environmental impacts. Tickell (2007) looked at the greenery and government relationship. In his research, the environmental degradation is accelerating and comprises five main elements including: population growth, deterioration of land quality, water pollution, changes in atmospheric chemistry and depletion of biodiversity. Tickell mentions that accompanying these processes is a growing public awareness of environmental issues.

Yunan et al. (2006) consider the CE a new development strategy in China on its path to industrialization. They notice that activities over the past several years show that CE is emerging as an economic strategy rather than a purely environmental strategy which it was initially known for. The major objective of the government is to promote the sustainable development of economy and society, while to achieve sustainable environmental protection. In another and related study, the issues of driving forces on China's CE from government's perspectives is studied by $\mathrm{Li}$ and $\mathrm{Li}$ (2011). In their view, there is a lack of driving forces for the developing $\mathrm{CE}$. The authors suggest adjusting the government behavior pattern in developing the CE so it contributes to the sustainable development of China's economy.

\subsection{Green Hydrogen Economy, Energy and Energy Tax}

Clark and Rifkin (2006) mention that it is too soon to face a hydrogen economy. In this situation, the authors suggest some concerns regarding the introduction of the hydrogen economy. The proliferation of hybrid vehicles is seen as a path towards energy independence and the seeking of a renewable or green hydrogen future in the near term. Their suggestion can be summarized as public efforts to introduce the mass marketing, infrastructure and funding that will boost technology innovations. Plus, they emphasize that LNG will be part of the transition, but because of its unstable characteristics as a major energy source, great priority needs to be placed on renewable sources of energy. In short, to enable sustainable growth, renewable energy production is a key issue and improvement of energy efficiency is only a strategy in the transition process. In a more recent study, Dow (2011) elaborates upon fuel cells and LEDs combined towards the green economy. Dow guides it is essential to develop cleaner and more efficient portable power systems that are based on hydrogen fuel cells.

The commonly used fossil fuels are scarce and depleteable primary energy sources. Baksi and Green (2007) mention that determinants of decline in economy-wide energy intensity include technical energy efficiency improvements in the economy, and also shifts in economic activity among the energy intensive sectors. In considering green energy strategies for sustainable development, Midilli et al. (2006) propose some green energy strategies for sustainable development. In this regard, seven green energy strategies are taken into consideration to determine the sectoral, technological, and application impact ratios. Based on these ratios, the authors derive a new and general parameter labeled as the green energy impact ratio. The sustainable energy strategies can make an important contribution to the economies of the countries where green energy is abundantly produced. 
Investment in green energy supply is recommended and encouraged by governments to replace fossil fuels.

In addition to public revenue generation, energy taxes are primarily designed to control energy consumption. Reduction in energy consumption is aimed at assisting the achievement of climate change control targets under the Kyoto Protocol. The political economy of energy taxes are fairly common in the European Union countries. Pearce (2006) looks at the factors that influence the policy design and provides guidelines on how these policies should help policy-oriented economists to design measures that have a greater chance of adoption. Energy conservation and CE in China concentrates on the process industries. Based on the introduction of the concept of energy consumption status in key energy-consuming process industries, the main technical bottlenecks and resourceenvironment problems were analyzed by $\mathrm{Li}$ et al. (2010). The special emphasis in this research is primarily upon few key factors including energy use efficiency, energy consumption mode, and waste emission.

Green energy refers to renewable energies. Green energy market development in Germany aims at effective public policy and the rapidly emerging customers' renewable energy demand. Wustenhagen and Bilharz (2006) review the development of renewable energy in Germany from 1973 to 2003. They investigate the relative importance of energy policy and green power marketing in shaping the renewable energy market in Germany. Similar to the non-renewable energy case, the political economy of green addresses the role of politics in environmental policymaking. Ciocirlan and Yandle (2003) discuss the public interest theory and alternative theories of regulation. They also explain the lack of environmental orientation of green taxes in the OECD countries. Abolhosseini (2014) provides a comprehensive review of the renewable energy market and describes characteristics of an optimal market with an emphasis upon technology, finances and regulations.

Energy efficiency and conservation are considered as major factors in the reduction of environmental impact of the energy sector. Linares and Labandeira (2010) discuss the factors that influence energy use in reduction-related decisions and propose appropriate policies for their promotion. Demand side management can be used to enhance sustainability in consumption. Worthington and Hoffman (2008) provide an empirical survey of residential water demand modeling. The increasing use of demand-side management as a tool to reliably meet electricity demands at peak time, has stimulated interest among stakeholders of the energy market. Heshmati (2014) reviews the literature and models on demand, customer base-line and demand response in the electricity market. An appropriate model for each case is combined and the implications of the results discussed.

Svendsen et al. (2001) studied consumers, industrialists and the political economy of green CO2 taxation in OECD. Economists have traditionally suggested that politicians should simply impose a uniform tax on harmful emissions. This policy is prescribed as the firstbest solution. The present empirical findings on CO2 taxation within the OECD countries confirms this theoretical prediction. Green taxes are to be considered as double dividends in a dynamic economy. Glomm et al. (2008) examine a revenue neutral green tax reform along the lines of the double dividend hypothesis. Using a dynamic general equilibrium 
model, the authors find that increasing gasoline taxes and use of the revenue to reduce capital income taxes delivers both types of welfare gains namely: an efficiency dividend and a green dividend. Oates (1995) asks whether we can both protect the environment and improve the tax system at the same time. The aim is also to explore some issues in the political economy of green taxes in a historical perspective. Nelson and Robertson (2008), in discussing environmental consequences of biofuels in the developing world, reviewed previous studies. They addressed the market and food security consequences of current rapid expansion in the demand for liquid biofuels vis-a-vis the environment in developing countries.

\subsection{Low Carbon Economy}

Low carbon economy is a basic economic development pattern seen from the ecological perspective. The development rules and practical development conditions of low carbon economy are considered in Chuanjiang and Ya (2011). Here the different aspects of development objective, path, method, technical and institutional innovations are also investigated. Foxon (2011) discusses a co-evolutionary framework for analyzing a transition to a sustainable low carbon economy. The transition is to be based on the coevolution of ecosystems, technologies, institutions, business strategies and user practices, within a multi-level micro-meso-macro perspective. For a long time California has been at the heart of the renewable energy industry. Green (2009) asks what it will take to bring a green economy into being and meet President Obama's goal of reducing carbon emissions to 80 percent below their 2005 levels by mid-century. Green is of the view that Obama's goal will succeed, but only if we have learned the lessons of three decades of failure.

Through building a green economy, climate scientists find it urgent to do something about the emissions of carbon dioxide and other greenhouse gases. Business as usual implies that we are facing a rise in global temperatures. In order to avoid disaster, we have to wean our economy from the use of fossil fuels-- in particular coal as a primary energy source. In this regard, Wei et al. (2011) discuss ecological civilization construction as the fundamental way to develop low carbon economy. They give a brief account of the characteristics and origin of ecological civilization and provide an analysis of its positive impacts on low carbon economy. Finally, the authors propose specific recommendations for constructing ecological civilization to develop the needed low carbon economy in a polluting Chinese economy.

The problems and strategies of the political economy of low carbon economy development is discussed in Xing et al. (2011). Low carbon economy is seen as the inevitable choice to tackle global warming and achieve sustainable development. The authors propose measures to achieve the development of China's low carbon economy. Wei and Xing and their associates view that low carbon economy is inevitable toward increasing the concentration of carbon dioxide which is causing global warming. The authors suggest that low carbon economy is economic growth pattern under the guidance of sustainable development. Xing et al. (2011) characterize low carbon economy as the externality that an economy produces is in fact of a global interest and the economy therefore must be 
developed in accordance with market economy. Development of low carbon economy is seen as the reflection of a series of innovations which should be entailed.

Other researches related to low carbon economy are Kane (2010) and Stanford (2011) who discuss the secrets of green business and unlocking a competitive advantage in a low carbon economy, which is a practical and easy to follow guide for businesses wishing to green their business. Krugman (2010) asks whether it is possible to make drastic cuts in greenhouse gas emissions without destroying our economy. He views that democratic domination in politics has a real chance with its political support for action on climate change. Under such conditions and with the knowledge on how to limit greenhouse gas emissions, as well as having a good sense of the costs, the emission cuts become manageable. All we need now is the political will to achieve the low carbon economy.

\section{Recent Green Developments}

The recent green developments include those related to ICT-based and knowledge-based innovations, green finance and investment, green trade and transport, and economic crisis, green jobs and welfare each described below.

\subsection{Green, ICT-based and Knowledge-based Innovations}

The green economy and its expansion are feasible only with innovation and new supportive sustainable development technologies. Phillimore (2001) analyses the Schumpeter, Schumacher and the greening of technology relationships. He looks at how compatible the ideas of neo-Schumpeterians and Schumacher are considering technology innovation and sustainable development. The results show that at one level, there appears to be a mutually reinforcing and positive relationship between the application of new technology, innovation and improved environmental performance. Innovation in the green economy in the form of a mix of green innovations, development of green industries, and resource allocation of green regions in an emerging green industry. These are investigated by Chapple et al. (2010). They find that innovation does not necessarily foster growth. Innovation boosts traditional firms, but emerging green firms need additional support to transform new ideas and products into new markets.

Information and communication technology (ICT) offers new technologies and opportunities to add to the successful implementation of a green economy. Johnston (2009) suggests that economic recovery is feasible through mobilizing ICT-based innovations. Johnston discusses Europe's realization of the potential of ICT-based innovations for a greener economy. Europe, as part of its Lisbon development strategy and investment in among others green technology, has supported this development. An important question to ask is what can IT do to be green? Ho and Metcalfe (2009) introduce the central concept of sustainability, namely life-cycle thinking. Three fundamental problems identified are importance and awareness of energy use, environmental protection, and the potential for climate change. The authors examine the role of IT in assisting sustainable activities and the importance of green activities and research into opportunities for sustainability are 
emphasized. Engelbricht (2009) emphasize efforts towards a knowledge-based economy perspective on the current crisis such that it takes human nature seriously. In particular, it should incorporate psychological factors like Keynes' 'animal spirits'.

The pressure from climate change and environmental deterioration implies the necessity of growing the green economy globally. Henderson (2007) studies the strategies for global sustainability and growing the green economy which must address economic models driving today's globalization. Henderson mentions that technological innovation is needed to shift from fossil fuels consumption patterns to renewable energy, recycling and redesign of industrial processes. Chua and Oh (2011) discuss the green developments initiatives, focusing on the national Green Technology Policy and its impacts on economic, environment and social developments.

Sustainable city policy is also considered by Camagni et al. (1998) as an economyenvironment-technology nexus. They make the effort to highlight the development of intervention policies to achieve a balanced 'sustainable city development'. Another measure of popularizing the greening behavior of the general public is through education. As an example, Haigh (2005) suggests greening the university curriculum to appraise an international movement. Haigh discusses barriers to the declaration of the 'United Nations decade of education for sustainable development' program, offering occasion for higher education institutions around the world to 'green' their curricula.

\subsection{Green Finances and Investments, Trade, Transports and Infrastructures}

To green the economy requires investment in new energy and production technologies. Green finance and the sustainable development of economy are discussed by $\mathrm{He}$ et al. (2003). Green finance is considered as an important tendency of modern financial institutions in developed countries. The new development has a significant meaning for the ecoenvironment, economic development and financial institutions. Heinkel et al. (2001) study the effect of green investment on corporate behavior. They explore the effect of exclusionary ethical investing on corporate behavior. Community currencies are also seen as a small change for a green economy. Seyfang (2001) critically evaluates the impact and potential of a community currency for local money system known as the 'local exchange trading scheme' to contribute to sustainable local green development. Findings from a case study in the UK indicate that community currency is successful in allowing participants to make small changes in their lifestyles, consumption, and employment patterns towards sustainable local development. However, there are limitations of size, scope, funding and management to be overcome before the objective to be achieved effectively.

Conconi (2003) in a theoretical study presents an agency model of policy making to examine how green lobbies affect the determination of trade and environmental policies in two large countries that are linked by trade flows and trans-boundary pollution. They examine the impact of green lobbying on environmental policy outcomes, under alternative assumptions about the trade agreement and the decision-making process and governments acts. The focus is first on the policies adopted by two symmetric countries under the influence of national green lobbies and then Conconi extends the analysis to the case in 
which governments are influenced by an international green lobby. They also explore the implications of country asymmetries. They show that the impact of green lobbying on environmental policy outcomes depends on the cooperativeness of trade regimes, on coordination among environmental agencies, and on the size of the emission leakages and trans-boundary spillovers.

Maestad (1998) also investigates the efficiency of a green trade policy. Maestad derives conditions for environmental policy when there are foreign trade partner countries which fail to implement appropriate environmental regulations. At the international level, Conconi suggests that the existence of WTO rules restricts the ability of governments to use trade barriers. This implies the need for the creation of a World Environmental Organization. However, if WTO rules are not binding, unilateral policy-making could lead to efficient policy outcomes. At the regional level, the members of preferential trade agreements like the EU, NAFTA and ASEAN can establish environmental cooperation. Söderholm (2008) analyzes the political economy of establishing bilateral trade between trade partners in green certificate markets. Some of the economic principles of an integrated bilateral green certificates market are outlined and a number of critical issues for its effectiveness, stability and legitimacy are further discussed.

Greening transport is an important area requiring explaining urban transport policy change. In general, transport policy has proven highly resistant to required changes despite full awareness about the growing environmental problems linked to transportation. Hysing (2009) explains how this 'greening' became a possibility. As an example, three variables of change in the case of Oresund in Sweden proved highly important to understand the nature of the policy change. The three variables include new policy ideas of sustainable transport, reorganization of the local administration and the pressure of green policy entrepreneurs. A common denominator behind all these changes was the reformation of urban transport into a political issue and it politicization. The continuing importance of politics is an important lesson from this case.

In many countries production and population concentration is changing as a result of urbanization and its directions. As an effort towards greening the rust belt, Schilling and Logan (2008) develop a green infrastructure model for right-sizing America's shrinking cities. They define a set of strategies that the shrinking cities can use to revitalize urban environments, empower community residents, and stabilize the dysfunctional real estate markets. They conclude with a few observations about potential policy reforms and research ideas. Right-sizing will require new ways to plan, design, and rebuild communities. Policy makers need legislative reforms, better data and solid research to advance these policy reforms and devoting effort to improving the diffusion of these policy innovations.

\subsection{Green Economy, Economic Crisis, Jobs and Welfare}

As part of efforts towards a green welfare economy, the Ggreen Party in Sweden, since the 1998 parliamentary election, have supported a coalition government being granted influence over government policies (Elander, 2007). This has led to a greening of the 
economy. As another measure of participation in policy making, Almås (1994) explores the agricultural policy cycle and assesses the nexus relation between state regulation, the liberalist market economy, and welfare support for the farmers in Norway. Changes in the cycle of agricultural policy result in changes in the farmers' survival strategies. The findings show that there is more persistence than change and farmers adapt themselves to anticipated policy changes. As a consequence, farmers used less fertilizer and pesticides even before the policy of 'green liberalism' was implemented.

Green taxes and double dividends in a dynamic economy are investigated by Glomm et al. (2008). They examine a revenue neutral green tax reform along the lines of the double dividend hypothesis. Based on a dynamic general equilibrium model, they find that increasing gasoline taxes and using the revenue to reduce capital income taxes in the U.S. does deliver both types of welfare dividend gains in form of an efficiency dividend and a green dividend. However, they find that, given the householders' willingness to pay for improvements in air quality, the size of the green dividend is much smaller than the efficiency dividend.

In the aftermath of the global economic crisis, significant investments have been made in green economy to create jobs in U.S. and Europe. Evidence of direct job creation effects of such investments is rare. There is suspicion that if any jobs are created, they are in low skill areas with temporary character and those less important for economic growth. Mehmet (1995) is a study that investigated employment creation and green development strategy in Indonesia. Mehmet argues for close ties between sustainable development and employment creating development.

Gai et al. (2011) investigates whether the relationship between green economy and green jobs is a myth or reality? This paper analyzes the direct and indirect employment impacts of two main greenhouse gas mitigation policies on the power generation sector in China. It proves that it is not simple to determine whether the policies bring more jobs. It is asserted that to ensure the co-existence of green economy and green jobs, policy makers should further promote renewable technologies. In addition, a matching of educational system and personnel structure is also needed.

Promoting the corporate social responsibility for a green economy and innovative jobs are among areas of interest with potential to be developed. Pop et al. (2011) analyze the role of social capital and promoting active aging in order to assure corporate social responsibility at national and international levels. It is considered as an efficient tool in combating the actual state of the economy in EU and in shifting to the new economy. As an outcome, the measure is expected in an integrated way to capitalize upon the knowledge, competences and abilities of the seniors. It could also create new innovative jobs and reinforce cooperation to promote green economy.

There is suspicion that the international community has been trying to get rid of the financial crisis, but it might further deteriorate the environmental crisis. The new approaches to the green economy of China focus on the multiple of crises. China has been got caught up in among others - environmental crisis, currency crisis, food and water resource crisis and ecological environment protection system crisis in the process of recent 
decades of the rapid development of the economy. With the severity of global environment and development problems, the green economy draws more attention. The keys are to formulate policies and systems to save energy, reduce the emission and develop new energy sources. This will help to usher into the ecological civilization, along the road of green economy. Jia et al. (2011) suggest the need to design the strategy and propel China toward ecological civilization accounting for the multiple dimensions of the crisis. Yang and Chen (2009) view the greening economy as a key solution to the global economic crisis. They mention that although the UN called for a Global Green New Deal as a response to the current financial and economic crisis and green stimulus incentives, there is no consensus on whether such green incentives will serve as a solution to the crisis or not.

The multiplicity of the crisis is called trilemma by Altwater (2009) by referring to the world economy, the financial crisis, and ecological sustainability. Capra and Henderson (2009) propose a qualitative growth approach which is a conceptual framework for finding solutions to our current crisis. The proposed approach should be economically sound, ecologically sustainable, and socially just. This global transition from environmental destruction to ecological sustainability is no longer a conceptual, nor a technical problem, but a problem of values and political will.

Engelbricht (2009) focuses upon a knowledge-based economy perspective on the current crisis. It is expected to take human nature seriously. It incorporates psychological factors like Keynes’ animal spirits. Development of a taxonomy recognizing the diversity of such economy should be accompanied by a reassessment of conventional welfare economics and the development of a new system that takes account of insights from research on subjective well-being and human behavior. Das (2002) in studying the relationship between green revolution and poverty reduction, examines the relation between technology and society, and critically reviews the positive and negative benefits of green economy on the poor in India. It is recommended that the association between poverty levels and the green revolution should be accepted with caution.

\section{Summary of Green Developments Tendencies}

Market economy focuses narrowly on technologies that produce marketable products and enhance productivity and profits. This productivity and profit trap is not conductive with environment and sustainability. Green ideology is about the nexus of justice, nature and political economy. It is not yet researched well, as the critique of contemporary industrial society is a relatively new and crucial phenomenon. Ecological and economic theories are developing to describe what should green GDP account for considering nonmarket benefits of nature. The European Commission efforts seem to be a step in the right direction to restructure its relationship with the civil society organizations to facilitate their active participation in green decision making that combines ecological modernization and economic security.

Green pressure shows the increase in concern over the environment. It has powered the green economy efforts which are evident from analysis of the electoral success of several green parties in Europe. The resulted green economy development strategy is shaping the 
direction that green economy optimally should follow. It concentrates particularly on the industrial system and its relationship to environmental politics. A desire has been growing to understand the link between economy and ecology towards sustainable development and the application of an integrated economic-ecological method and analysis. The emergence of sustainable city policy is one measure that highlights the development of intervention and integrated policies to achieve a balanced and sustainable city development. This gradually is developing into a sustainable economy that is less harmful to environment and more easily applicable.

The resource-environment problems in process industry have implied special emphasis on primary energy supply, energy use efficiency, energy consumption mode, material use and waste emission. Efforts are also made to eliminate green barriers to implement circular production processes and clean production techniques. Circular economy is developed as a national policy for sustainable development to deal with the environment effects of China's economic miracle. This is emerging as an economic strategy rather than a purely environmental strategy. Despite great interest in and its superiority, circular and traditional economies will coexist. A comparison and analysis between the two systems helps to assess the nature of their coexistence and the speed of substitution. CE parallel implementation at the firm, industry and national levels to address environmental degradation and resource scarcity is assessed as promising. However, different measures of promotion of a CE, and developing and strengthening its driving forces, are required to attain a sustainable development path.

The agricultural policy cycle is aiming at the nexus between regulation, the market economy, and support to the farmers with environment in focus. The main challenge is to produce enough food that can feed the world's growing population. Green economy, as a sustainable and effective approach, is to improve economic development, to control environmental deterioration and to increase yield without deteriorating regional disparity, vulnerability and famine conditions. A quality-based model for green product development which addresses environmental issues through product design and innovation is receiving attention from customers, industries and states. Green technology adoption trends should play an important role in sustaining productivity growth. Green business is a new perspective upon management and business ethics. The growing greening of industry network is another example of a contemporary environmental social movement. The political economy of international green certificate markets is also a major step towards ecopolitical economy of the green economy.

The accelerating environmental degradation has led to a growing public awareness of environmental issues serving as a driving force upon development of ways like CE. The composition, goals, and practices of some social actors and green citizenship in the green economy movement are crucial for the development of green capacities and their implementations. Green waves and globalization is moving towards equity and environmental justice. Studies of green movement perceptions and behavioral intentions are important. Green chemistry as social movement provide conditions under which segments of civil society can participate in social movements. The social movements by being granted influence over government policies can improve upon the optimal policy 
model of promoting green economy. Considering issues of equality, examinations of relation between technology and society can shed lights on the positive and negative benefits of green economy on the poor and marginalized.

A green hydrogen economy as a path for countries to be energy independent and seeking a renewable future is increasingly emphasized. More efficient portable power systems are among other measures. A sizable decline in energy intensity, technical efficiency improvements, and shifts in economic activity among economic sectors have also been achieved. Energy conservation in China's process industries and green or renewable energy market development in Germany emphasize effective public policy and emerging green customer demand. The political economy of green taxation addresses the role of politics in environmental policymaking. However, the theories of regulation are still not sufficiently developed to have a strong environmental orientation. Energy taxes are designed to control energy consumption, and to assist the achievement of climate change control targets. Green taxes are expected to provide double dividend in forms of efficiency and green dividends.

Low-carbon economy is emerging as a basic economic development pattern, the inevitable choice to tackle global warming and the way to achieve the goal of sustainable development. A co-evolutionary transition to a sustainable low carbon economy within a multi-level micro-meso-macro perspective is desirable. In building a green economy, climate scientists suggest to do something about emissions of carbon dioxide and other greenhouse gases by weaning our economy from the use of fossil fuels. However, despite the benefits of such measures, there is a fear that rapid and drastic cuts in greenhouse-gas emissions would harm our economy. The market and food security consequence of rapid expansion in demand for liquid biofuels is another source of concern.

Innovation in the green economy is in the form of a mix of green innovation, industries, and regions. There is a desire to realize the potential of ICT-based innovations not only as measure of economic recovery, but also for a greener economy. It is important that there is a mutually reinforcing and positive relationship between the application of new technology, innovation and improved environmental performance. Growing the green economy globally require innovation technologies and strategies for global sustainability. Consistent with global sustainability strategies, the national green technology policy and their impacts on economic, environment and social developments need to be focused upon. Sustainable city policy and greening university curriculum are among measures in line with an economy-environment-technology-education nexus to achieve balanced sustainable development.

Green finance is an important tendency of modern financial institutions with significant implications for sustainable development of the economy and its effects on corporate behavior and social responsibility. In this regard, community currencies, if managed well, can contribute to sustainable local development. Green finance is also linked to green trade, transport and infrastructure and is impacted by green movements, lobbies and policies. Green trade policy also encourages foreign countries that fail to implement appropriate environmental regulations to act green. Greening transport and in particular urban transport policy and its changes are becoming possible due to growing 
environmental problems and concerns. This has even impacted the issue of right-sizing the cities and optimal green infrastructure to sustainable development.

New research show that large shares of consumers have strong inclinations to buy earthsustainable food products. Consumers have also shown high willingness to pay a premium for green products, initiatives and practices of services like the hotel industry. Development of quality-based models for green products and markets might become a success. They address environmental issues through product design and innovation, as opposed to the traditional end-of-pipe-control approach. Among other measures are green payments for nonpoint pollution control to reduce agricultural nonpoint-source pollution.

The green national product implies adjustment of the national product for the value of environmental damages. Green accounting can be used for assessment of the sustainability of economic activities and growth. This shows that the negative scale effect of economic growth on the environment can be compensated by increasing the weight of less polluting productions and by a technical progress favorable to the environment. This is in line with the concept of qualitative growth aiming at finding solutions to our current crisis that are economically sound, ecologically sustainable, and socially just. A productivity trap should be avoided that arises from the systematic pursuit of higher labor productivity. Development of research on green economy needs to be utilized to managing the shift towards green productivity and green GDP measuring of the national economy.

The growing green parties are being granted influence over governmental green and welfare policies. The literature on the Green Revolution and poverty show evidence of the relationship between technology and society and their benefits on the poor. In recent years corporate social responsibility is being promoted for a green economy and innovative jobs. It is considered an efficient tool in combating the recession and in shifting to the new economy with strong green elements. Employment creation and green development strategy argues for close ties between sustainable developments at different levels of aggregation.

However, measures to reduce impact of economic crisis might deteriorate the environment. There is no consensus that greening economy serves as a solution to the crisis, but undoubtedly it impacts the environment and sustainability. The ultimate objective must be to find solutions to the crisis of the world economy, the financial crisis, and ecological sustainability that are economically sound, ecologically sustainable, and socially just both within and between regions and countries. The active participation of different stakeholders in decisions, as well as strong and efficient national and international monitoring organizations will determine the quality of this critical and life-changing outcome.

\section{Acknowledgement}

The author gratefully acknowledges receipt of research grant from the Sogang University Climate Changes and Economic Diagnoses (SRF). 


\section{References}

Aaheim A. and K. Nybory (1995). On the interpretation and applicability of a "Green National Product”. Review of Income and Wealth 41(1), 57-71.

Abolhosseini S. (2014). The impact of renewable energy development on carbon emission reduction, Ph.D. Thesis in Engineering, TEMEP, College of Engineering, Seoul National University.

Adams W.M. (2001). Green development: environment and sustainability in the Third World, New York: Routledge.

Almås R. (1994). The rise and fallof agricultural policy cycles: From planned economy to green liberalism. Journal of Rural Studies 10(1), 15-25.

Altvater E. (2009). World economy, the financial crisis, and ecological sustainability - A trilemma. Capitalism Nature Socialism 10(4), 37-68.

Archibugi F. and P. Nijkamp (1989). Eds, Economy and ecology: Towards sustainable development, Kluwer, Dordrecht.

Asheim G.B. (1997). Adjusting green NNP to measure sustainability, Scandinavian Journal of Economics 99(3), 355-370.

Baksi S. and C. Green (2007). Calculating economy-wide energy intensity decline rate: The role of sectoral output and energy shares. Energy Policy 35, 6457-6466.

Barry J. (2001). Justice, nature and political economy. Economy and Society 30(3), 381394.

Barry J. (2007). A model of green political economy: From ecological modernisation to economic security. International Journal of Green Economics 1(3-4), 446-464.

Bartelmus P. (2013). The future we want: Green growth or sustainable development? Environmental Development 7, 165-170.

Bartelmus P. (1999). Green accounting for a sustainable economy: Policy use and analysis of environmental accounts in the Philippines. Ecological Economics 29, 155-170.

Boyd J. (2007). Nonmarket benefits of nature: What should be counted in green GDP? Ecological Economics 61, 716-723.

Cai W., C. Wang, J. Chen and S. Wang (2011). Green economy and green jobs: Myth or reality? The case of China's power generation sector. Energy 36, 5994-6003.

Cairns R.D. (2002). Green national income and expenditure. The Canadian Journal of Economics 35(1), 1-15.

Camagni R., R. Capello and P. Nijkamp (1998). Towards sustainable city policy: an economy-environment technology nexus. Ecological Economics 24, 103-118.

Capra F. and H. Henderson (2009), Qualititatibe growth, the institute of chartered accountants in England and Wales.

Carfi D. and D. Schiliro (2012). A cooperative model for the green economy. Economic Modelling 29, 1215-1219.

Carraro C., A. Favero and E. Massetti (2012). Investments and public finance in a green, low carbon, economy. Energy Economics 34, 515-528.

Chakravarti A.K. (1973). Green Revolution in India. Annals of the Association of American Geographers 63(3), 319-330.

Chapple K., C. Kroll, T.W. Lester and S. Montero (2010). Innovation in the green economy, Industry Study Association. 
Chen C. (2001). Design for the environment: A quality-based model for green product development, Management Science 47(2), 250-263.

Chen H. (2008). On the optimal policy model of promoting green economy, Economic Geography 28(4), 598-602.

Ciocirlan C.E. and B. Yandle (2003). The political economy of green taxation in the OECD countries. European Journal of Law and Economics 15, 203-218.

Chua S.C. and T.H. Oh (2011). Green progress and prospect in Malaysia. Renewable and Sustainable Energy Reviews 15, 2850-2861.

Chuanjiang L. and F. Ya (2011). Low-carbon economy; Theoretical study and development path choice in China. Energy Procedia 5, 487-493.

Clark W.C. and J. Rifkin (2006). A green hydrogen economy. Energy Policy 34, 2630-639.

Conconi P. (2003). Green lobbies and transboundary pollution in large open economies. Journal of International Economics 59, 399-422.

Das R.J. (2002). The green revolution and poverty - theoretical and empirical examinations of relation between technology and society. Geoforum 33, 55-72.

Dawe D. (1998). Reenergizing the green revolution in Rice. American Journal of Agricultural Economics 80(5), 948-953.

Despommier D. (2013). Farming up the city: the rise of urban vertical farms. Trends in Biotechnology 31(7), 388-389.

Dow S. (2011). Fuel cells and LEDs combine to light the way towards the green economy. Fuel Cell Bulletin, August 2011, 12-14.

Edwards P.E.T., A.E. Sutton-Grier and G.E. Coyle (2013). Investing in nature: Restoring coastal habitat blue infrastructure and green job creation. Marine Policy 38, 65-71.

Elander I. (2007). Towards a green welfare economy - the green party in Sweden since the 1998 parliamentary election. Environmental Politics 9(3), 137-144.

Engelbricht H.J. (2009). Pathological knowledge-based economies: towards a knowledgebased economy perspective on the current crisis. Prometheus 27(4), 403-414.

Eyraud L., B. Clements and A. Wane (2013). Green investment: Trends and determinants. Energy Policy 60, 852-865.

Färe, R., S. Grosskopf and Jr. C.A. Pasurka (2001). Accounting for air pollution emissions in measures of state manufacturing productivity growth. Journal of Regional Science 41(3), 381-409.

Faxla-Raymond N., E. Svendsen and L.K. Campbell (2013). From job training to green jobs: A case study of a young adult employment program centered on environmental restoration in New York City, USA. Urban Forestry and Urban Greening 12(3), 287295.

Fonseca S.A. and C.J.C. Jabbour (2012). Assessment of business incubator' green performance: A framework and its application to Brazilian cases. Technovation 32, 122-132.

Foster A.D. and M.R. Rosenzweig (1996). Technical change and human capital returns and investments: Evidence from the green revolution. American Economic Review 86(4), 931-953.

Foxon T.J. (2011). A coevolutionary framework for analyzing a transition to a sustainable low carbon economy. Ecological Economics 70(12), 2258-2267. 
Gai C., C. Wang, J. Chen and S. Wang (2011). The relationship between green economy and green jobs: myth or reality? The case of China's power generation sector. Energy 36(10), 5994-6003.

Geng Y., J. Fu, J. Sarkis and B. Xue (2011). Towards a national circular economy indicator system in China: an evaluation and critical analysis. Journal of Cleaner Production xx, 1-11.

Geng Y. Q. Zhu, B. Doberstein and T. Fujita (2009). Implementing China's circular economy concept at the regional level: A review of progress in Dalian, China. Water Management 29, 996-1002.

Geng Y. and B. Doberstein (2008). Developing the circular economy in China: Challenges and opportunities for achieving 'leapfrog development'. International Journal of Sustainable Development \& World Ecology 15. 231-239.

Glomm G., D. Kawaguchi and F. Sepulveda (2008). Green taxes and double dividends in a dynamic economy. Journal of Policy Modeling 30, 19-32.

Gollin D., M. Morris and D. Byerlee (2005). Technology adoption in intensive post-green revolution systems. American Journal of Agricultural Economics 87(5), 1310-1316.

Green J. (2009). The elusive green economy. Ideas: Energy \& Environment, July/August 2009 Atlantic,

Greenwood D. (2007). The halfway house: Democracy, complexity, and the limits to markets in green political economy. Environmental Politics 16(1), 73-91.

Grover R.B. (2013). Green growth and role of nuclear power: A perspective from India. Energy Strategy Reviews 1, 255-260.

Haigh M. (2005). Greening the university curriculum: appraising an international movement. Journal of Geography in Higher Education 29(1), 31-48.

Hartman H. (1996). Myths and realities of the "new" green economy. Environmental Quality Management 6(2), 47-55.

He J.K., Jiang T. and W. Wang (2003). “Green finance” and the sustainable development of economy. Green Economy 00, 78-81.

Heberling M.T., J.J. Templeton and S. Wu (2012). Green net regional product for the San Luis Basin, Colorado: An economic measure of regional sustainability. Journal of Environmental Management 111, 287-297.

Heinkel R., A. Kraus and J. Zechner (2001). The effect of green investment on corporate finance. Journal of Financial and Quantitative Analysis 36, 431-449.

Henderson H. (2007). Growing the green economy globally. International Journal of Green Economics 1(3-4), 276-298.

Heshmati A. (2014). Demand, customer base-line and demand response in the electricity market: A Survey. Journal of Economic Surveys, in Press.

Ho S.M. and C.F. Metsalfe (2009). Life-cycle thinking: What can IT do to be green? iConference'09, Feb 8-11, 2009, Chapel Hill, NC, USA.

Horan T.D., J.S. Shortle and D.G. Abler (1999). Green payments for nonpoint pollution control. American Journal of Agricultural Economics 81(5), 1210-1215.

Horlings L.J. and T.K. Marsden (2011). Towards the real green revolution? Exploring the conceptual dimensions of a new ecological modernisation of agriculture that could 'feed the world'. Global Environmental Change 21, 441-452. 
Huang L.H., W.X. Lin, Y.C. Guo and F.Y. Chen (2002). Green economy and sustainable development. Chinese Journal of Eco-Agriculture 10(2), 139-140.

Hunold C. (2007). Green political theory and the European Union: The case for a nonintegrated civil society. Environmental Politics 14(3), 324-343.

Hysing E. (2009). Greening transport - explaining urban transport policy change. Journal of Environmental Policy and Planning 11(3), 243-261.

Jackson T. and P. Victor (2011). Productivity and work in the 'green economy' - some theoretical reflections and empirical tests. Environmental Innovation and Societal Transitions 1, 101-108.

Jacobs M. (1991). The green economy: Environment, sustainable development and the politics of the future, Pluto Press, Concord, MA 1991/Westview Press, Boulder CO, 1993.

Jamison A. (2001). Environmentalism in an entrepreneurial age: reflections on the greening of industry network. Journal of Environmental Policy and Planning 3(1), 113.

Jia X., Q. Sun and Y. Gao (2011). New approaches to the green economy of China in the multiple crisis. Energy Procedia 5, 1365-1370.

Jiang Y. and L.J. Zhou (2012). Study on green supply chain management based on circular economy. Physics Procedia 25, 1682-1688.

Johnston P. (2009). Economic recovery to a greener economy: mobilizing ICT-based innovations, Policy Brief, European Policy Centre, July 2009.

Johnson D.B. (2008). Green businesses: perspectives from management and business ethics. Society and Natural Resources 11, 259-266.

Kane G. (2010). The three secrets of green business: Unlocking competitive advantage in a low carbon economy, Earthscan, Lodon.

Kang K.H., L. Stein, C.Y. Heo and S. Lee (2011). Customers' willingness to pay for green initiatives for the hotel industry. International Journal of Hospitality Management 31(2), 564-572.

Klooster D. (2003). Book Review, Green Development: Environment and Sustainability in the Third World, W. M. Adams, 2nd Rev. Ed., New York: Routledge, 2001, Professional Geongrapher 55(1), 112-114.

Kosoy N., P.G. Brown, K. Bosselman, A. Duraiappah, B. Mackey, J. Martinez-Alier, D. Rogers and R. Thomson (2012). Pillars for a flourishing earth: planetary boundaries, economic growth delusion and green economy. Current Opinion in Environmental Sustainability 4, 74-79.

Kotchen M.J. (2003). green markets and private provision of public goods, Williams College, Unpublished.

Krugman P. (2010). Building a green economy, New York Times, April 5, 2010.

Lee D.H., S.Y. Park, J.C. Hong, S.J. Choi and J.W. Kim (2013). Analysis of the energy and environmental effects of green car deployment by an integrating energy system model with a forecasting model. Applied Energy 103, 306-316.

Lehtinen A.A. (2007). Green waves' and globalization: A Nordic view on environmental justice. Norwegian Journal of Geography 60(1), 46-56. 
Li. H., W. Bao, C. Hu, Y. Zhang and H. Xu (2010). Energy conservation and circular economy in China's process industry. Energy 35, 4273-4281.

Li J., S.J. Hartman and S.M.L. Zee (2009). A study of green movement perceptions and bebavioural intentions. International Journal of Sustainable Economy 1(2), 133-143.

Li R.H. and C.H. Su (2012). Evaluation of the circular economy development level of Chinese chemical enterprises. Procedia Environmental Sciences 13, 1595-1601.

Li S. (2012). The research on quantitative evaluation of circular economy based on waste input-output analysis. Procedia Environmental Science 12, 65-71.

Li X. and Y. Li (2011). Driving forces on China's circular economy: from government's perspectives. Energy Procedia 5, 297-301.

Lin E.Y.Y., P.Y. Chen and C.C. Chen (2013). Measuring green productivity of country: a generalized metafrontier Malmquist productivity index approach. Energy 55, 340-353.

Linares P. and X. Labandeira (2010). Energy efficiency: economics and policy. Journal of Economic Surveys 24(3), 573-592.

Maestad O. (1998). On the efficiency of green trade policy. Environmental and Resource Economics 11, 1-18.

Margulis L. and R. Fester (1991). Eds. Symbiosis as a source of evolutionary innovation: Speciation and morphogenesis. The MIT Press.

Matthews J.H. and F. Boltz (2012). The shifting boundaries of sustainability science: Are we doomed yet? PLoS Biology 10(6), e1001344.

McCulloch A. (2008). Green pressure. Contemporary Record 4(3), 10-12.

Mehmet O. (1995). Employment creation and green development strategy. Ecological Economics 15, 11-19.

Mendonca M., D. Jacobs and B. Sovacool (2010). Powering the green economy - the feedin tariff handbook, Earthscan, London.

Mellor M. (2006). Ecofeminist political economy. International Journal of Green Economics 1(1/2), 139-150.

Midilli A., I. Dincer and M. Ay (2006). Green energy strategies for sustainable development. Energy Policy 34, 3623-3633.

Mohanty R.P. and S.G. Deshmukh (1998). Managing green productivity: some strategic directions. Production Planning and Control 9(7), 624-633.

Musu I. (2010). Green Economy: great expectation or big illusion?, Working Paper No.1, 2010, University of Venice.

Muuller-Rommet F. (2007). Explaining the electoral success of green parties: A crossnational analysis. Environmental Politics 7(4), 145-154.

Nelson G.C. and R.D. Robertson (2008). Green gold or green wash: environmental consequences of biofuels in the developing world. Review of Agricultural Economics, 30, 517-529.

Oates W.E. (1995). Green taxes: Can we protect the environment and improve the tax system at the same time? Southern Economic Journal 61(4), 915-922.

Oh D.H. and A. Heshmati (2010). A sequential Malmquist-Luenberger productivity index: Environmentally sensitive productivity growth considering the progressive nature of technology. Energy Economics 32(6), 1345-1355 (SSCI). 
Opschoor H. (1991). Book Review, The green economics: Environment, sustainable development and the policies of the future, M. Jacobs, Pluto Press, Concord, MA, 1991/Westview Press, Boulder CO, 1991. Ecological Economics 22(3), 256.

Paterson M. (2007). Political economies of sustainability. Environmental Politics 16(1), 147-153.

Pearce D. (2006). The political economy of an energy tax: The United Kingdom's climate change levy. Energy Economics 28, 149-158.

Pearce D., A. Markandya and B. Barbier (1989). Man at the centre of row? Blueprint for a green economy, Earthscan Publications, London, UK.

Phillimore J. (2001). Schumpeter, Schumacher and the greening of technology. Technology Analysis and Strategic Management 13(1), 23-37.

Pop O., G.C. Dina and C. Martin (2011). Promoting the corporate social responsibility for a green economy and innovative jobs. Procedia Social and Behavioral Sciences 15, 1020-1023.

Prieels A.M. (1990). Value and the environment. Futures, May 1990, 436-439.

Puppim de Oliveira J.A., C.N.H. Doll, O. Balaban, P. Jiang, M. Dreyfus, A. Suwa, R. Moreno-Penaranda and P. Dirgahayani (2013). Green economy and governance in cities: assessing good governance in key urban economic processes. Journal of Cleaner Production 58, 138-152.

Reilly J.M. (2012). Green growth and the efficient use of natural resources. Energy Economics 34, 585-593.

Roarty M. (1997). Greening business in a market economy. European Business Review 97(5), 244-254.

Sari H. and Hasnelly (2012). Factors determining green companies performance in Indonesia: a conceptual model. Procedia Social and Behavioral Sciences 57, 518-523.

Sayer A. (2000). Moral economy and political economy. Studies in Political Economy 61, 71-103.

Schilling J. and J. Logan (2008). Greening the rust belt: A green infrastructure model for right sizing America's shrinking cities. Journal of the American Planning Association 74(4), 451-466.

Schmalensee R. (2012). From "green growth" to sound policies: An overview. Energy Economics 34, 52-56.

Seyfang G. (2001). Community currencies: small change for a green economy. Environment and Planning A 33, 975-996.

Seyfang G. and N. Longhurst (2013). Growing green money? Mapping community currencies for sustainable development. Ecological Economics 86, 65-77.

Shear B. (2010). The green economy: Grounds for a new revolutionary imaginary? Rethinking Marxism 22(1), 203-209.

Smith G. (2005). Green citizenship and the social economy. Environmental Politics 14(2), 273-289.

Söderholm P. (2008). The political economy of international green certificate markets. Energy Policy 36, 2051-2062. 
Stanford D. (2011). Book Review: The three secrets of green business: Unlocking competitive advantage in a low carbon economy, Gareth Kane, Earthscan, London 2010. Tourism Management 32, 1484-1490.

Stavrakakis Y. (1997). Green ideology: a discursive reading. Journal of Political Ideologies 2(3), 259-279.

Svendsen G.T., C. Daugbjerg, L. Hjollund and A.B. Pedersen (2001). Consumers, industrialists and the political economy of green taxation: CO2 taxation in OECD. Energy Policy 29, 489-497.

Thornton D.B. (2013). Green accounting and green eyeshades twenty years later. Critical Perspectives on Accounting 24, 438-442.

Tickell C. (1997). Greenery and governance. International Journal of Environmental Studies 53, 235-246.

Turner R.K. (1992). Book review: Economy and ecology: Towards sustainable development. F. Archibugi and P. Nijkamp (Editors). Kluwer, Dordrecht, 1989. Economy and Ecology 1, 177-180.

Turner S.C. and W. Kriesel (1995). The relative importance of the green industry in the U.S. agricultural economy. Journal of Agribusiness 13(1), 51-62.

Twidell J. (2010). Book Review: Powering the Green Economy - the feed-in tariff handbook, M. Mendonca, D. Jacobs and B. Sovacool, Earthscan, London, 2010. Energy 35, 4618-4619.

UNEP (2011). Towards a green economy: Pathways to sustainable development and poverty reduction - A synthesis for policy makers. www.unep.org/greeneconomy

Ustaoglu M. and B. Yildiz (2012). Innovative green technology in Turkey: electric vehicles' future and forecasting market share. Procedia Social and Behavioral Sciences 41, 139-146.

van der Ploeg R. and C. Withagen (2013). Green growth, green paradox and the global economic crisis. Environmental Innovation and Social Transitions 6, 116-119.

Vellinga N. and C. Withagen (1996). On the concept of green national income. Oxford Economic Papers 48, 499-514.

Von Weizsacker E.U. (1994). Sustainable economy. The Science of Total Environment 143, 149-156.

Wall D. (2001). Review article, Green anti-capitalism. Environmental Politics 10(3), 151154.

Wang Y. and L. Liu (2007). Green barriers from the standpoint of sustainable development. Journal of Economic Policy Reform 10(3), 233-240.

Wang Y., X. Huang and L. Wang (2011). The development research of green economic in capital cities in Shandong. Energy Procedia 5, 130-134.

Wei Z., L. Hulin and A. Xuebing (2011). Ecological civilization construction is the fundamental way to develop low-carbon economy. Energy Procedia 5, 839-843.

Weitzman M. (1976). On the welfare significance of national product in a dynamic economy. Quarterly Journal of Economics 90, 156-162.

Woodhouse E.J. and S. Breyman (2005). Green chemistry as social movement? Science, Technology, \& Human Values 30(2), 199-222. 
Worthington A.C. and M. Hoffman (2008). An empirical survey of residential water demand modelling. Journal of Economic Surveys 22(5), 842-871.

WRI (2011). A compilation of green economy policies, programs, and initiatives from around the world, World Resources Institute, The green economy in practice: interactive workshop, February 11, 2011.

Wustenhagen R. and M. Bilharz (2006). Green energy market development in Germany: effective public policy and emerging customer demand. Energy Policy 34, 1681-1696.

Xin X.S. (2006). New idea of checking the green economy. Ecological Economy 00, 8788.

Xing X., Y. Wang and J. Wang (2011). The problems and strategies of the low carbon economy development. Energy Procedia 5, 1831-1836.

Yang Y. (2001). Thoughts of green economy development strategy. China Academic Journal Electronic Publishing House 6, 49-52.

Yang Y. and I. Chen (2009). Greening economy as a key solution to the economic crisis. ACE 0, 215-222.

Yapa L.S. (1979). Ecopolitical economy of the green revolution. Professional Geographer 31(4), 371-376.

Yi H. (2013). Clean energy policies and green jobs: an evaluation of green jobs in U.S. metropolitan areas. Energy Policy 56, 644-652.

Young M. and C. Esau (2013). Investing in water for a green economy - Services, infrastructure, policies and management. Routledge, Milton Park, New York.

Yuan Z., J. Bi, and Y. Moriguichi (2006). The circular economy: A new development strategy in China. Industrial Ecology in Asia 10(1-2), 4-8.

Zhang A.W. and J.F. Chen (2004). Comparison and analysis between circular economy and traditional economic theory. China Academic Journal Electronic Publishing House 10, in Press.

Zhang C.X. and S.P. Su (2005). Development of green economy under stood from the viewpoint of system theory. Chinese Journal of Eco-Agriculture 13(1), 7-9.

Zsolnai L. (2002). green businesses or community economy? International Journal of Social Economics 29(8), 652-662. 